\title{
Study on the Development of Agricultural Product Logistics in the Context of Internet
}

\author{
Juxiang Zhang \\ Tan Kah Kee College, Xiamen University, ZhangZhou, China \\ 14827686@qq.com
}

Keywords: Internet plus, agricultural products logistics, countermeasures

\begin{abstract}
In recent years, the scale of agricultural products logistics industry continues to expand in China. However, there are many problems of agricultural products logistics, such as poor logistics infrastructure, low degree of agricultural informatization, shortage of talent, lack of quality and safety supervision system and so on. "Internet plus" is a new engine for the development of agricultural product logistics. From the "Internet plus agricultural products logistics" perspective, this paper puts forward relevant countermeasures and suggestions, such as strengthening construction of logistics infrastructures, establishing agricultural products databases, constructing a public logistics information platform, developing agricultural logistics entities, strengthening talent training, and constructing quality and credit certification system.
\end{abstract}

\section{Introduction}

Traditional agricultural products logistics has a long circulation cycle and large loss of agricultural products. Moreover, it is difficult to detect the quality of agricultural products in transit process. In recent years, the scale of China's agricultural products logistics continues to expand. Statistics show that in 2016 China's total agricultural logistics reached 3 trillion and 600 billion RMB, increased by $3.1 \%$ compared to last year. However, in comparison with industrial products logistics which achieves 214 trillion RMB and grows by $6 \%$ on the corresponding period, China's agricultural logistics is still at a low level of development ${ }^{[1]}$.

With the further development of information technology, Chinese has entered the "Internet plus" era. "Internet plus" brings innovation power for the development of agricultural products logistics. Through the implementation of the strategy of " Internet plus agriculture", agricultural products logistics can break the inherent closed mode, integrate business flow, logistics, and information flow to construct a new market mode, which accomplishes complementary advantages and win-win.

\section{2. "Internet Plus" Concept}

"Internet plus" refers to the combination of Internet and traditional industries by means of modern information technology and Internet platform to create a new ecological economy ${ }^{[2]}$. "Internet plus traditional industry" is neither the simple sum of the two nor the replacement of traditional industries, but to realize the deep integration and innovative development of Internet and traditional industries. The integration of Internet and manufacturing, transportation, catering, finance, entertainment and other industries embodies the development of knowledge innovation, technological innovation and social innovation. "Internet plus" will bring new business models, stimulate various social and market potential. For agricultural products logistics, "Internet plus" has brought new opportunities, will become the new engine of development.

\section{Status of Agricultural Products Logistics}

3.1 Agricultural Products Logistics Process. Agricultural product logistics is a series of economic activities to transport agricultural output from agricultural producers to customers. The basic process of agricultural products logistics includes production, classification, packaging, storage, 
transportation and distribution; it needs farmer cooperative organizations, all levels of farmers market, Logistics companies, catering and other departments involve and cooperate ${ }^{[3]}$, as shown in figure 1.

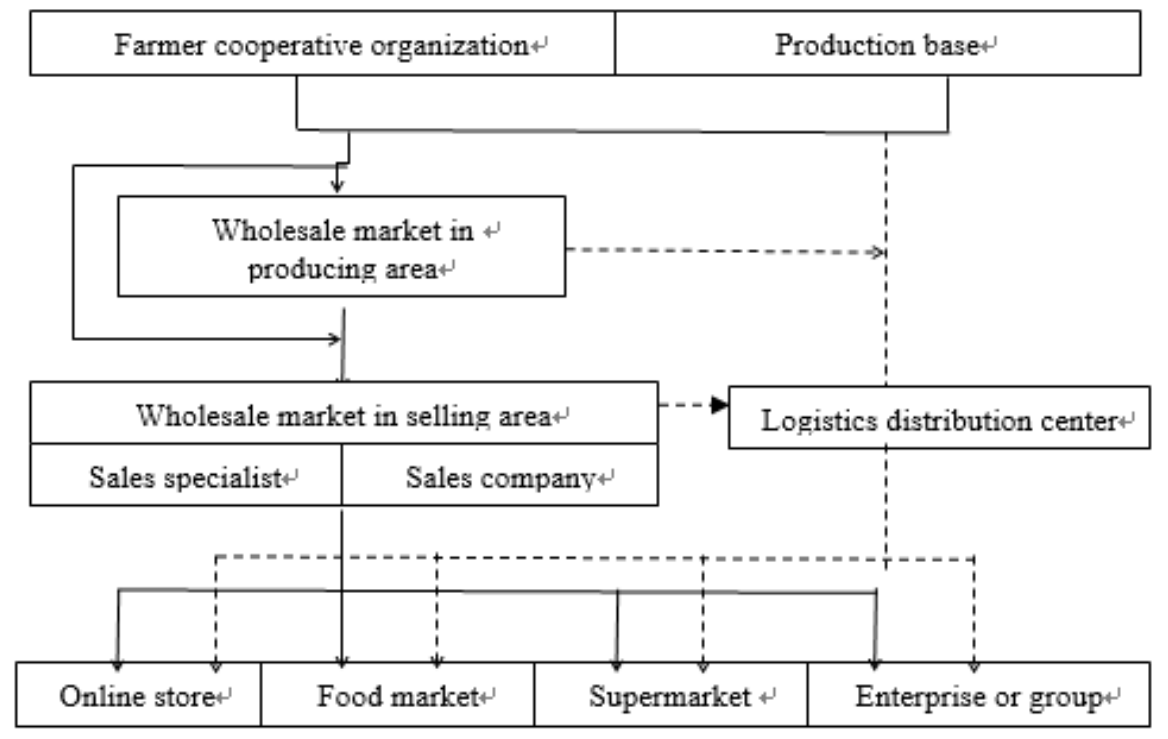

Fig.1. The process of agricultural products logistics

\subsection{Present Situation of Agricultural Products Logistics}

3.2.1 Initial Establishment of Agricultural Products Logistics System. A large number of agricultural products market are built in China, which has greatly promoted the development of agricultural products logistics. However, Logistics enterprises, facilities and logistics activities are mainly concentrated in urban areas with convenient transportation, and the development of rural logistics industry is relatively slow. In addition, agricultural market laws and regulations are imperfect, and standardizations of agricultural products trading are lack. Since there are many intermediate links, the logistics cost is high. Although the storage and processing industry of agricultural products has been rising, the development level is low and the scale is small.

3.2.2 Preliminary Establishment of Agricultural Information System. In recent years, a number of agricultural electronic information platform are established in china. The information of agricultural products can not only be transmitted through traditional media such as TV and radio programs, but also can be shared in agricultural information websites such as "Shandong Shouguang vegetable market network", "Chinese agricultural products marketing network platform" and so on [4] Agricultural electronic information platform help agricultural entities to grasp various logistics market information, which promotes the development of agricultural logistics.

3.2.3 Diversification of Logistics Entities. In China, there are a large number of diversified agricultural products logistics entities including many individuals and small groups, so that the agricultural products logistics entities has the characteristics of low level, high dispersion, and low competitiveness. Transactions are becoming diversified as well. In addition to the traditional trading modes, there are new trading patterns such as futures trading, credit transactions trust transactions, etc., in order to meet the needs of different varieties, different quantity and different distance of the agricultural products circulation.

\section{Problems in the Development of Agricultural Products Logistics}

4.1 Poor Logistics Infrastructure. The agricultural logistics infrastructure construction, including rural roads, warehousing, wholesale markets, and information platform, has been lagged behind. Complete transportation networks have not formed, leading to long transit time. Besides, cold chain logistics is lagging behind. Agricultural products are fresh perishable goods which need professional cold chain transport equipment. Nevertheless, the current cold chain system is incomplete; the infrastructure and transport facilities are extremely backward, resulting in large products loss. The 
shortage of agricultural products storage facilities is short as well, storage technology is backward, and the degree of mechanization is low. Thus, the cost of fresh agricultural products storage and transportation accounts for more than $50 \%$ of the total cost, resulting in weak competitiveness of agricultural logistics.

4.2 Low Degree of Agricultural Informatization. The starting point of agricultural logistics is in rural areas. In recent years, with the government's increasing investment in the network communication infrastructure, the mobile phone network is almost full coverage, and broadband network are also connected in most of the rural areas. However, the farmers' access rate is not high, and the application of Internet in agricultural products sales and logistics is still low. At present, China's agricultural informationization is still in the spontaneous stage; most agricultural products information lack of connection, each forms an "Information Island".

Low degree of agricultural informatization results in cluster production and excess supply of similar agricultural products in the market. Both farmers and agricultural enterprises suffer huge economic losses. At present, little agricultural electronic information platform contains the whole agricultural information. Thus, it is difficult for logistics enterprises to obtain accurate information of production and consumption in the market, and accordingly it is hard to optimize the construction of hardware devices and Route planning.

4.3 Low Specialization Degree of Agricultural Entities. "Internet plus" era has put forward higher requirements for agricultural logistics. Making full use of the Internet technology, big data technology, strengthening supervision and optimization of logistics technology have become the new norm of modern logistics. However, the main entities of traditional agricultural products circulation are farmers and small traders who have poor preservation technology and transportation technology, causing large cost fluctuations. In addition, the specialization level of third party agricultural products logistics is still low.

4.4 Shortage of Agricultural Logistics Talents. On the one hand, many college graduates are not willing to engage in agricultural related works; on the other hand, in recent years the logistics industry develops rapidly driven by E-commerce, leading to lack of talents especially for agricultural products logistics. In the traditional circulation, many farmers and small traders undertake the task of agricultural products logistics. Usually they are not well educated, have little understanding of Internet and low level of information technology; hence it is difficult for them to meet the demand of modern agricultural logistics in the "Internet plus" era.

4.5 Lack of Quality and Safety Supervision System. In the current market of agricultural products, there is no perfect agricultural product quality monitoring system, supply and demand forecast system, and safety warning system, resulting in lack of quality and quantity guarantee of agricultural products. Similarly, owing to lack of supervision mechanism in agricultural products logistics, there are still some problems such as low level of food safety awareness, poor cold chain logistics equipment and so on, which cannot guarantee the quality and safety of agricultural products ${ }^{[5]}$.

\section{Countermeasures for the Development of Agricultural Products Logistics}

5.1 Improving Logistics Infrastructures. Complete infrastructures are an important condition for the development of agricultural products logistics. Trading centers, storage facilities, technical tools and transport equipment are the main infrastructure of agricultural products logistics. The government should support and increase investment in infrastructure construction, improve warehouse operation, improve the professional level of transportation equipment, promote logistics technology and processing skills, so that the classification, packaging, storage and transportation level of agricultural products can get great progress ${ }^{[6]}$. The government should also formulate fiscal and taxation policies that contribute to the development of agricultural products logistics.

5.2 Constructing An Agricultural Products Database. The government should improve the construction of rural Internet infrastructure and information network; reduce the cost of access and use for farmers. All agricultural information platforms should be linked to establish an agricultural products database. Making full use of big data technology to integrate, analyze, process agricultural 
products database so as to select useful data to construct information center. Those effective information resources in information center will be transmitted to all entities of agricultural products logistics for decision-making.

5.3 Establishing A Public Logistics Information Platform. It is necessary to utilize the "cloud" technology to integrating various information of logistics entities, agricultural products to construct a public logistics information platform. The public logistics information platform is a comprehensive logistics service platform. The main task is to quickly deal with customer orders, schedule and command of all kinds of logistics resources, provide transportation, warehousing, distribution monitoring and other services. Besides, the platform has functions of transportation capacity to query, real-time transaction, vehicle tracking, goods traceability as support to visualize the logistics process. With the big data analysis techniques, the platform is able to optimize the logistics network layout, transport routes, transportation schedules, warehouse layout, storage space, which integrates the whole logistics supply chain to reduce the cost and improve the efficiency ${ }^{[7]}$.

All logistics providers assemble in this platform, such as warehousing companies, transportation companies, third party logistics, fourth party logistics companies, freight forwarding companies, to provide customers with a full range of logistics services.

5.4 Strengthening Agricultural Logistics Entities. The modern agricultural logistics entities is the key to develop "Internet plus" agricultural products logistics. It is necessary to cultivate specialized and large-scale agricultural logistics entities. Firstly, a variety of agricultural cooperatives should be developed, which extensively collaborate with other logistics entities to broaden the channels of agricultural logistics. Secondly, leading enterprises of agricultural products need to be cultivated, which establish various forms of associations with farmers and production bases to improve the circulation efficiency. Thirdly, agricultural logistics enterprises should be vigorously developed, especially specialized and large-scale third party logistics enterprises. Through the specialized operation of the third party logistics, it can reduce the unnecessary intermediate links in the circulation of agricultural products and improve the logistics efficiency.

5.5 Strengthening Talent Training. Talent is the decisive factor in the development of "Internet plus" agricultural products logistics. A large number of professionals about storage, processing, distribution, computer maintenance, and management are demanded. It is necessary to cultivate all kinds of logistics talents by formal education, on-the-job training, or pre job training.

First of all, logistics education should be vigorously developed. The government should expand the enrollment scale of logistics undergraduate and graduate students in Colleges and universities, and encourage more young people to engage in the works of agricultural products logistics. Secondly, agricultural products logistics personnel need to be trained. Professional trainings help to improve technical level of employees. Thirdly, trainings should also be provided for farmers. They need Internet technique, modern logistics knowledge and other skills, helping them adapt to new requirements of "Internet plus" agricultural products logistics.

5.6 Developing Quality and Credit Certification Systems. Due to the differences in the origin and production process, and lack of uniform quality certification standards, agricultural products quality standards are not uniform. It is hard to judge the quality and freshness of agricultural products simply through text or picture online, which hinders agricultural products online trading to a large degree. Therefore, it is imperative to build a unified quality certification system of agricultural products.

E-commerce is a virtual transaction and usually the transaction risk is higher than the real deal. Thus, it is necessary to construct agricultural e-commerce credit certification system, which can effectively constrain transaction partners and control risk Moreover, for agricultural products electronic information platforms, the credibility level should be an important reference for information collection and product promotion.

\section{Conclusion}

At present, there are many problems in the development of agricultural products logistics in China. "Internet plus" strategy creates new opportunities for agricultural product logistics. With the help of 
"Internet plus" thinking, a series of countermeasures are proposed to promote agricultural logistics informatization and standardization, such as speeding up the construction of logistics infrastructure, establishing agricultural products databases, constructing a public logistics information platform, developing agricultural logistics entities, talent training, and constructing quality and credit certification system. "Internet plus" strategy helps to break "information island", promote the transportation efficiency of agricultural products logistics, and bring great value.

\section{References}

[1] Xinhuanet. http://news.xinhuanet.com/fortune/2017-03/09/c_1120599149.htm

[2] Yang Wenxiu, Zhou Li, and Zhang Xiaolin, Countermeasures analysis on promoting of the development of Internet+ agriculture products logistics, Logistics Engineering and Management, vol. 38, pp. 113-114, 2016.

[3] Bai Hua, Problems and countermeasures of agriculture e-commerce logistics, Agricultural Resources and Regionalization in China, vol.37, pp. 176-179, 2016.

[4] Song Xuan, Research on the development of China's agriculture products logistics under the background of internet, Journal of Anhui Agriculture Science, vol.43, pp. 299-300, 2015. )

[5] Xia Huan, Li Shuang, Ye Qing, Under the background of great poverty alleviation "big data + agricultural products logistic" strategy, Information Technology and Informatization, vol.3, pp. 76-78, 2016.

[6] Li Yuqing, Research on the current situation and solution of China's agricultural products logistics, Agriculture Network Information, vol.1, pp. 103-105, 2014.

[7] Shi Xianliang, the Development trend of agriculture products logistics and countermeasures, China Business and Market, vol.7, pp. 25-29, 2015. 